\title{
Pengembangan Modul Praktikum IPA SMP Kontekstual pada Materi Pencemaran Lingkungan untuk Meningkatkan Keterampilan Proses Sains dan Karakter Peduli Lingkungan
}

\author{
Ni Luh Putu Rusmana Dewi ${ }^{1}$, I Wayan Suastra ${ }^{2}$, Ni Made Pujani ${ }^{3}$ \\ 1,2,3 Program Studi Pendidikan IPA, Program Pascasarjana \\ Universitas Pendidikan Ganesha \\ Singaraja, Indonesia \\ e-mail: rusmana.dewi@pasca.undiksha.ac.id ${ }^{1}$, wayan.suastra@pasca.undiksha.ac.id², \\ made.pujani@pasca.undiksha.ac.id ${ }^{3}$
}

\begin{abstract}
Abstrak
Penelitian ini bertujuan untuk menghasilkan modul praktikum IPA berbasis kontekstual yang memenuhi kelayakan, kepraktisan, dan keefektivan dalam meningkatkan keterampilan proses sains dan karakter peduli lingkungan. Jenis penelitian ini adalah penelitian dan pengembangan $(R \& D)$. Prosedur pengembangan mengacu pada jenis pengembangan yang dikemukakan Thiagarajan yang dimodifikasi menjadi define, design, dan development. Data validitas modul praktikum dinilai oleh dua orang tenaga ahli dari kalangan dosen. Data kepraktisan dinilai oleh empat orang guru IPA dan sepuluh siswa. Data keefektifan modul praktikum didapatkan melalui uji lapangan terbatas yang dilakukan di SMP Bintang Persada Denpasar dengan melibatkan kelas VII sebanyak 30 orang. Hasil uji validitas, kepraktisan, dan efektivitas modul praktikum dianalisis secara deskriptif. Hasil penelitian menunjukkan bahwa: (1) nilai validitas modul praktikum 3,40 termasuk dalam kategori valid, (2) kepraktisan modul praktikum berada pada kategori sangat praktis dengan nilai keterlaksanaan modul praktikum terus meningkat, dan skor respon guru rata-rata 3,54 dan (3) keefektivan modul praktikum dilihat dari keterampilan proses sains berada dalam kategori baik dan skor karakter peduli lingkungan siswa berada dalam kategori mulai berkembang. Berdasarkan temuan tersebut dapat disimpulkan modul praktikum IPA Kontekstual yang dikembangkan memenuhi kriteria valid, praktis, dan efektif sehingga layak dan dapat diimplemantasikan di sekolah.
\end{abstract}

Kata Kunci: Modul praktikum IPA ,kontekstual, keterampilan proses sains, karakter peduli lingkungan

\begin{abstract}
This research purpose to produce science practicum module based on contextual which has validity, practicability, and effective to improving science process skills and environmental caring character. This type of research is research and development $(R \& D)$. The development procedure refers to the development model that Thiagarajan proposes that is modified to define, design, and develop. The validity of the module of practicum has been validated by two experts lecturer. Practicality was jugged by four science teachers and ten students as a sample. The effectiveness data of the practicum module was obtained through a limited field trial conducted at SMP Bintang Persada Denpasar involving VII class of 30 people. The results of the validity, practicality, and effectiveness of the module were analyzed in descriptivel. The results showed that: (1) the validity of the practicum module is 3.40 and belong to valid category, (2) the practicality of practicum module belongs to very good category in which the application value had increased continuously, and the score of teachers' responses approximately 3.54, and (3) the effectiveness of the practicum module viewed from the skills of the science process belong to good category and the score of students' environmental cares belong to developing category. Based on these findings, it can be concluded that the developed Contextual Science practice module was valid, practical, and effective criteria so that it is feasible and can be implemented in schools.
\end{abstract}

Keywords: Science practice module, contextual, science process skills, environmental caring charact 


\section{Pendahuluan}

Saat ini pemerintah sedang berusaha meningkatkan kualitas Sumber Daya Manusia baik fisik, mental,maupun spiritual. Hal ini dikarenakan SDM yang berkualitas dapat menjadi pionir pembangunan bangsa Indonesia ke arah yang lebih baik, cerdas dalam menghadapi perkembangan jaman serta peduli terhadap permasalahan lingkungan. Kualitas SDM tersebut salah satunya dapat ditingkatkan melalui peningkatan mutu pendidikan yakni dengan penyempurnaan kurikulum secara kontinu di semua jenjang pendidikan

Namun berdasarkan fakta yang ditemukan, menunjukkan bahwa kualitas pembelajaran IPA di Indonsia masih rendah. Fakta ini dibuktikan data TIMSS tahun 2011, menunjukkan bahwa kemampuan siswa Indonesia dalam bidang sains masih rendah. Siswa cenderung hanya mampu mengenal sebagian fakta-fakta dasar, tetapi belum mampu menalar, menganalisis dan menerapkan pengetahuan sains dalam kehidupan nyata (Gonzales et al.,2009). Hasil TIMSS tahun 2015 juga mengungkapkan bahwa secara umum, siswa Indonesia lemah di semua konten kognitif termasuk kemampuan mengintegrasikan informasi, menarik simpulan, serta menggeneralisir pengetahuan yang dimiliki (Rahmawati, 2015). Selanjutnya, Data Programme for International Student Assesment (PISA) tahun 2006, menunjukkan bahwa pelajar Indonesia yang memiliki kemampuan melakukan penelitian sederhana seperti praktikum hanya sebanyak $27,5 \%$. Selanjutnya, Presentase kemampuan mengidentifikasi masalahmasalah ilmiah hanya $9,5 \%$, sedangkan pelajar yang mampu memanfaatkan sains untuk kehidupan sehari-hari hanya 1,4\%. Hasil PISA tersebut memberikan gambaran bahwa pendidikan Sains di Indonesia belum mampu meningkatkan keterampilan proses Sains siswa (OECD, 2015).

Salah satu penyebab rendahnya kemampuan sains ksususnya keterampilan proses sains dikarenakan praktikum belum banyak dilakukan sebagai sumber belajar siswa, padahal materi IPA khususnya pencemaran sangat banyak aplikasinya dalam kehidupan sehari-hari siswa di lingkungan (Mehyandoko, 2013). Hal ini dapat dibuktikan berdasarkan hasil penelitian Efendi (2010) yang menyimpulkan bahwa pembelajaran saat ini belum memberikan kesempatan pada siswa untuk memperoleh pengetahuan tentang alat, metode dan prosedur. Selanjutnya, Suastra et al. (2006) juga menunjukkan bahwa penilaian yang digunakan untuk menilai hasil belajar siswa 100\% hanya mengukur aspek kognitif yaitu dengan menggunakan kuis, ulangan akhir pokok bahasan, ulangan umum dan tugas rumah tanpa menilai unjuk kerja siswa sehingga kemampuan sains siswa menjadi kurang berkembang.

Permasalahan lainnya yang juga terjadi dalam dunia pendidikan adalah munculnya krisis dalam watak atau karakter bangsa khususnya karakter kepedulian terhadap lingkungan. Faktor yang menyebabkan merosotnya karakter kepedulian terhadap lingkungan dikarenakan pembelajaran di sekolah belum banyak yang menanamkan pendidikan karakter kepada peserta didik. Fakta ini didukung oleh hasil penelitian yang dilakukan oleh (Meyhandoko,2013), bahwa masih banyak pembelajaran di sekolah yang hanya melakukan transfer ilmu dan pengetahuan saja ke peserta didik tanpa menyisipkan nilai-nilai luhur atau pendidikan karakter sehingga mulai berdampak pada kemerosotan akhlak dan perilaku yang tidak bertanggungjawab seperti membuang sampah sembarangan, mencorat-coret tempat umum serta sikap ketidak pedulian terhadap lingkungan lainnya menjadi cerminan pendidikan suram masa lalu di masa kini.

Berdasarkan hasil observasi di SMP Bintang Persada Denpasar, ditemukan bahwa petunjuk praktikum yang ada masih minim khususnya pada materi pencemaran. Petunjuk praktikum yang ada sebelumnya masih memiliki kelemahan, diantaranya, petunjuknya masih terbatas, kurang menyajikan gambar, belum menggunakan bahasa yang interaktif, dan materi maupun prosedur yang ada sulit dipahami karena tidak mengaitkan dengan situasi dunia nyata sehingga belum sesuai dengan kondisi kontekstual peserta didik. Penerapan nilai karakter dalam proses praktikum dirasa juga masih kurang. Hal ini dibuktikan dari hasil wawancara penulis dengan guru IPA di sekolah tersebut ditemukan bahwa masih ada siswa diketahui kurang memiliki kepedulian terhadap lingkungan yang salah satunya ditandai dengan perilaku membuang sampah tidak pada tempatnya.

Sebagai pemecahan atas permasalahan di atas, perlu dikembangkan bahan ajar berupa modul praktikum. Krakteristik dari modul praktikum yang dikembangkan adalah disesuaikan dengan kehidupan sehari-hari siswa (kontekstual) yang dimodifikasi dengan perangkat praktikum yang sederhana. Salah satu cara agar praktikum dapat dilakukan dengan mudah adalah dengan mengkaitkannya dengan situasi nyata di lingkungan siswa (kontekstual). Melalui cara ini, praktikum akan lebih menarik dan menyenangkan bagi siswa karena membawa persoalan IPA ke dalam kehidupan sehari-hari sehingga dapat memfasilitasi pengembangan 
keterampilan proses sains siswa dan kepedulian siswa terhadap lingkungan (Wahid, 2001). Semiawan (dalam Suastra, 2013) juga menyatakan bahwa alasan yang melandasi perlunya diterapkan pendekatan keterampilan proses IPA dalam kegiatan pembelajaran salah satunya adalah anak-anak akan lebih mudah memahami konsep yang rumit dan abstrak jika disertai dengan contoh-contoh konkret yang sesuai dengan kondisi yang dihadapi serta mempraktekkaan sendiri sebagai upaya penemuan konsep.

Nurhadi et al. (dalam Meyhandoko, 2013) menyatakan, pembelajaran konstektual adalah konsep belajar dengan menghadirkan dunia nyata ke dalam kelas dan mendorong siswa membuat hubungan antara pengetahuan yang dimilikinya serta penerapannya dalam kehidupan sehari-hari. Hal ini sebagai bekal siswa untuk memecahkan masalah dalam kehidupannya sebagai anggota masyarakat. Ketika kegiatan praktikum dilakukan dengan pendekatan kontekstual, maka akan terjadi interaksi pengetahuan yang telah dimiliki siswa dengan lingkungan tempat belajar. Dengan demikian, peningkatan kebermaknaan dan ketertarikan terhadap materi IPA semakin meningkat sehingga keterampilan proses sains siswa juga akan meningkat. Hal ini didukung oleh penelitian Ting \& Siew (2014), menyatakan bahwa keterampilan proses sains siswa mengalami peningkatan ketika belajar dengan di luar kelas (kontekstual). Belajar di luar kelas dapat membantu siswa untuk membangun lebih banyak struktur kognitif yang kompleks dengan kegiatan nyata. Melalui interaksi antara lingkungan, siswa akan dapat menerapkan keterampilan proses sains untuk memecahkan masalah seharihari yang lebih baik. Satriani \& Emilia ( 2012), mengungkapkan bahwa CTL dapat diimplementasikan dalam pengajaran menulis bahasa Inggris, sehingga akan efektif juga apabila diterapkan pada pembelajaran di kelas.

Selain itu praktikum dengan pendekatan kontekstual dapat berdampak positif terhadap peningkatan karakter siswa. Pernyataan ini didukung oleh hasil penelitian Yustina \& Febrita (2013), yang memberikan informasi bahwa pembelajaran berbasis Lingkungan (kontekstual) berdampak positif terhadap sikap dan partisipasi siswa, dengan melibatkan siswa dalam pembelajaran dengan lingkungan dapat meningkatkan budaya kepedulian siswa terhadap lingkungan. Karakter didefinisikan sebagai watak batin yang dapat diandalkan untuk menanggapi situasi secara moral. Karakter mengandung tiga bagian yang saling terkait yakni moral knowing, moral feeling, dan moral behavior (Lickona, 2015). Sementara menurut Kemdiknas (2001), karakter diartikan sebagai tabiat, sifat-sifat kejiwaan, akhlak atau budi pekerti yang membedakan seseorang dengan yang lain, dan watak. Jadi karakter merupakan sifat alami seseorang dalam merespon situasi secara bermoral yang diyakini dan digunakan sebagai landasan untuk cara pandang, berpikir, bersikap, dan bertidak untuk hidup dan bekerjasama dalam masyarakat.

Selanjutnya, karakter peduli lingkungan merupakan sikap dan tindakan yang selalu berupaya mencegah kerusakan lingkungan alam di sekitarnya dan mengembangkan upayaupaya untuk memperbaiki kerusakan alam yang sudah terjadi. Indikator ketercapaian nilai-nilai peduli lingkungan di antaranya sebagai berikut; 1) Kerja keras untuk melindungi alam, 2) Menghargai kesehatan dan kebersihan, 3) Bijaksana dalam menggunakan SDA, dan 4) Tanggung jawab terhadap lingkungan. Mulyasa (2014) menyatakan, proses penerapan karakter dalam kehidupan sehari-hari peserta didik dapat dilakukan melalui pembelajaran Kontekstual, karena pembelajaran dilakukan secara alamiah, sehingga peserta didik dapat mempraktikkan karakter-karakter yang dipelajarinya dan yang telah dimilikinya secara langsung. Pembelajaran kontekstual mendorong peserta didik memahami hakikat, makna, dan manfaat belajar, sehingga memungkinkan mereka termotivasi belajar bahkan mampu membentuk kesadaran diri untuk mempertimbangkan dan mengambil tindakan moral dalam bentuk karakter yang positif , salah satunya karakter peduli terhadap lingkungan.

Berdasarkan latar belakang masalah tersebut, maka peneliti tertarik untuk mengembangkan modul praktikum IPA Kontekstual pada materi pencemaran lingkungan untuk meningkatkan keterampilan proses sains dan karakter peduli lingkungan. Modul praktikum IPA yang dikembangkan tersebut diharapkan dapat memberikan alternatif dalam pelaksanaan praktikum di sekolah, sehingga keterampilan proses sains dan karakter peduli lingkungan siswa akan mengalamipeningkatan.

Oleh karena itu peneliti merasa perlu untuk melakukan penelitian dan pengembangan dengan judul "Pengembangan Modul Praktikum IPA SMP Kontekstual” menurut peneliti layak untuk diangkat sebagai sebuah penelitian.

Berdasarkan uraian latar belakang di atas, maka permasalahan yang dirumuskan dalam penelitian ini adalah: (1) Bagaimanakah validitas produk yang dikembangakan?, (2) Bagaimana kepraktisan produk yang dikembangakan?, (3) Bagaimana keefektifan produk yang 
dikembangkan untuk meningkatkan keterampilan proses sains?, (4) Bagaimana keefektifan produk yang dikembangkan untuk meningkatkan karakter peduli lingkungan?

\section{Metode}

Penelitian ini diarahkan pada pengujian model melalui pengembangan suatu produk bahan ajar IPA SMP. Metode yang digunakan adalah penelitian dan pengembangan (Research and Development). Produk yang dikembangkan adalah Modul Praktikum IPA SMP Kontekstual untuk kelas VII semester kedua pada materi pencemaran lingkungan.

Model pengembangan bahan ajar yang digunakan pada penelitian ini adalah model pengembangan yang disarankan oleh Thiagarajan et al. (1974) adalah model 4-D, Model ini terdiri dari 4 tahap pengembangan, yaitu define (Pendifinisian), design (Perencanaan), develop (Pengembangan), dan disseminate (Penyebaran). Diadaptasi menjadi model 3-D, yaitu pendefinisian, perancangan dan pengembangan, tanpa dilakukan penyebaran karena keterbatasan peneliti.

Uji Coba penelitian ini dilakukan di SMP Bintang Persada Denpasar pada siswa kelas VIla tahun pelajaran 2016/2017 dengan jumlah siswanya sebanyak 30 orang. Teknik pengumpulan data yang digunakan dalam penelitian ini adalah dengan menggunakan beebrapa instrumen seperti: 1) lembar validasi bahan ajar, 2) lembar obsevasi keterlaksanaan pembelajaran, 3) angket respon guru, 4) angket respon siswa, 5) lembar observasi keterampilan proses sains, 6) lembar observasi karakter peduli lingkungan, dan 7) angket karakter peduli lingkungan.

Produk bahan ajar yang dihasilkan dikatakan memiliki kualitas baik jika memenuhi tiga aspek, yaitu validitas, kepraktisan, dan efektifitas. Oleh karena itu untuk menentukan kualitas bahan ajar yang dikembangkan diperlukan tiga macam data yaitu validitas, kepraktisan, dan efektivitas. Adapun kriteria validitas, kepraktisan dan efektifvitas.

Tabel 1. Kriteria Validitas Perangkat Pembelajaran

\begin{tabular}{cc}
\hline Skor & Kategori \\
\hline $3,5 \leq \mathrm{Sr}<4,0$ & Sangat valid (sangat layak) \\
$2,5 \leq \mathrm{Sr}<3,5$ & Valid (layak) \\
$1,5 \leq \mathrm{Sr}<2,5$ & Tidak valid (tidak layak) \\
$1,0 \leq \mathrm{Sr}<1,5$ & Sangat tidak valid (sangat tidak layak) \\
\hline
\end{tabular}

(Gregory, 2000)

Tabel 2. Kriteria Kepraktisan Perangkat Pembelajaran

\begin{tabular}{lcc}
\hline & Skor & Kategori \\
\hline $3,5 \leq \mathrm{Sr}<4,0$ & & Sangat praktis \\
$2,5 \leq \mathrm{Sr}<3,5$ & & Praktis \\
$1,5 \leq \mathrm{Sr}<2,5$ & & Tidak praktis \\
$1,0 \leq \mathrm{Sr}<1,5$ & & Sangat tidak praktis \\
\hline
\end{tabular}

(Gregory, 2000)

Tabel 3. Kriteria Keterampilan Proses Sains

\begin{tabular}{lcc}
\hline & Skor & Kategori \\
\hline $90-100$ & Sangat Baik \\
$80-89$ & Baik \\
$65-79$ & Cukup \\
$55-64$ & Kurang Baik \\
$0-54$ & Sangat Kurang Baik
\end{tabular}

(diadaptasi dari Nurkancana \& Sunartana, 1986) 
IVCEJ, Vol 1 No 2, Tahun 2018

p-ISSN: 2615-4684 e-ISSN: 2615-6938

Tabel 4. Kriteria Karakter Peduli Lingkungan

\begin{tabular}{lcc}
\hline & Skor & Kategori \\
\hline $3,5 \leq \mathrm{Sr}<4,0$ & & Membudaya \\
$2,5 \leq \mathrm{Sr}<3,5$ & & Mulai berkembang \\
$1,5 \leq \mathrm{Sr}<2,5$ & & Mulai terlihat \\
$1,0 \leq \mathrm{Sr}<1,5$ & & Belum terlihat \\
\hline
\end{tabular}

(Gregory, 2000)

Modul praktikum yang dikembangkan dikatakan telah memiliki keefektifan dalam meningkatkan keterampilan proses sains siswa bila mencapai kategori minimal baik dan dikatakan telah memiliki keefektifan meningkatkan karakter peduli lingkumgan siswa bila minimal rata-rata skornya 2,5 dengan katagori mulai berkembang.

\section{Hasil dan Pembahasan}

Hasil dari penelitian ini berupa porduk Modul Praktikum IPA SMP Kontekstual pada materi pencemaran lingkungan dengan Total praktikum yang dikembangkan adalah sebanyak 6 kegiatan praktikum, dengan tema sebagai berikut; 1) ciri-ciri air tercemar, 2) metode penjernihan air , 3) pencemaran udara di lingkungan sekitar , 4) pencemaran asap rokok , 5) pencemaran tanah di lingkungan sekitar, dan 6) pengaruh detergen terhadap pertumbuhan tanaman.Modul Praktikum yang dikembangkan untuk peserta didik SMP mengacu kepada kurikulum 2013 yang sedang diterapkan di sekolah-sekolah.

\section{Validitas Modul Praktikum}

Modul Praktikum sebelum diuji cobakan divalidasi terlebih dahulu oleh ahli untuk mengetahui kelayakan dari produk. Validasi modul praktikum dilakukan oleh dua orang dosen sebagai ahli isi dan desain. Para validator memberikan validasi produk secara kuantitatif dan kualitatif pada lembar validasi. Rata-rata hasil penilaian dapat dilihat pada Tabel 5.

Tabel 5. Hasil Penilaian Validator Terhadap Modul Praktikum Pada Setiap Aspek

\begin{tabular}{cccc}
\hline No & Aspek yang Dinilai & Skor Validasi & Ket \\
\hline 1 & Kelayakan Isi & 3,54 & Sangat Valid \\
2 & Kelayakan Penyajian/Tampilan & 3,37 & Valid \\
3 & Penilaian Bahasa & 3,30 & Valid \\
\hline \multicolumn{2}{l}{ Jumlah } & $\mathbf{1 0 , 2 1}$ & \\
\hline & Rata-Rata & $\mathbf{3 , 4 0}$ & Valid \\
\hline
\end{tabular}

Berdasarkan hasil validasi modul praktikum pada Tabel 5., maka modul praktikum berkategori valid.

\section{Kepraktisan Modul Praktikum}

Tahap selanjutnya uji kepraktisan dilakukan dengan menggunakan empat orang praktisi dari kalangan guru IPA dan sampel siswa sebanyak 10 orang yang dilaksanakan di SMP Bintang Persada Denpasar. Pada saat uji kepraktisan ini saran yang konstruktif ditindak lanjuti sehingga Modul Praktikum yang dihasilkan benar-benar memiliki kualitas yang baik sesuai dengan harapan. Kepraktisan bahan ajar dapat diketahui dari: 1) keterlaksanaan bahan ajar, 2) respon guru dan 3) respon siswa. Bahan ajar dikatakan praktis bila rata-rata skor total minimal atau sama dengan 2,5. Berikut ditampilkan hasil uji kepraktisan Modul Praktikum.

Tabel 6. Hasil Observasi Keterlaksanaan Modul Praktikum

\begin{tabular}{cccc}
\hline No & Aspek yang Dinilai & Skor Praktisi & Katagori \\
\hline 1 & Kemudahan dalam penggunaan & 3,54 & Sangat Praktis \\
2 & Kesesuaian dengan waktu & 3,38 & Praktis \\
3 & Manfaat yang diperoleh & 3,60 & Sangat Praktis \\
\hline
\end{tabular}




\begin{tabular}{ccc}
\hline Jumlah & 10,52 & \\
\hline Rata-Rata & 3,50 & Sangat Praktis \\
\hline
\end{tabular}

Tabel 7. Hasil Respon Guru Terhadap Modul Praktikum

\begin{tabular}{cccc}
\hline \multirow{2}{*}{ No } & Aspek Penilaian & Skor Rata-Rata & Kategori \\
\hline 1 & Kemudahan Pelaksanaan & 3,70 & Sangat Praktis \\
2 & Kesesuaian Isi & 3,91 & Sangat Praktis \\
3 & Kesesuaian Waktu & 3,00 & Praktis \\
\hline & Jumlah & $\mathbf{1 0 , 6 2}$ & Sangat Praktis \\
\hline
\end{tabular}

Tabel 8. Hasil Respon Siswa Terhadap Modul Praktikum

\begin{tabular}{cccc}
\hline No & Aspek Penilaian & Skor Rata-rata & Kategori \\
\hline 1 & Tampilan & 3,65 & Sangat Praktis \\
2 & Penyajian materi & 3,35 & Praktis \\
3 & Manfaat & 3,61 & Sangat Praktis \\
\hline & Jumlah & $\mathbf{1 0 , 6 1}$ & \\
\hline & Rata-rata akhir & $\mathbf{3 , 5 3}$ & Sangat Praktis \\
\hline
\end{tabular}

Berdasarkan data Tabel 6, rata-rata skor total keterlaksanaan modul praktikum yang diujicobakan yaitu 3,50 dalam kategori sangat praktis. Sedangkan respon guru terhadap modul praktikum yang diujicobakan diperoleh skor 3,54 dan respon siswa terhadap keterlaksanaan modul praktikum yang diujicobakan diperoleh skor 3,53 keduanya dengan kategori sangat praktis.

\section{Efektivitas Modul Praktikum}

Keefektifan modul praktikum yang dikembangkan diketahui dari nilai keterampilan proses sains dan skor peduli lingkungan siswa. Hasil observasi keterampilan proses sains dan karakter peduli lingkungan dilakukan pada setiap pertemuan. Hasil uji efektivitas modul praktikum dapat dapat diamati pada 9 dan 10.

Tabel 9. Hasil Keterampilan Proses Sains Pada Setiap Indikator

\begin{tabular}{clcc}
\hline No. & Indikator & Nilai & Kategori \\
\hline 1 & Merumuskan Hipotesis & 90,13 & Sangat Baik \\
2 & Melakukan Percobaan & 84,86 & Baik \\
3 & Melakukan Pengamatan & 85,27 & Baik \\
4 & Menerapkan Konsep & 85,97 & Baik \\
5 & Mengkomunikasikan & 83,05 & Baik \\
\hline \multicolumn{2}{l}{ Rata-Rata Total } & $\mathbf{8 5 , 8 6}$ & Baik \\
\hline
\end{tabular}

Tabel 10. Rata-rata Nilai Karakter Peduli Lingkungan Siswa

\begin{tabular}{clcc}
\hline No. & \multicolumn{1}{c}{ Indikator } & Skor Rata-rata & Kategori \\
\hline 1 & $\begin{array}{l}\text { Kerja keras untuk melindungi } \\
\text { alam }\end{array}$ & 3,51 & Membudaya \\
2 & $\begin{array}{l}\text { Menghargai kesehatan dan } \\
\text { kebersihan }\end{array}$ & 2,99 & Mulai Berkembang \\
\hline
\end{tabular}


IVCEJ, Vol 1 No 2, Tahun 2018

p-ISSN: 2615-4684 e-ISSN: 2615-6938

\begin{tabular}{clcl}
\hline 3 & $\begin{array}{l}\text { Bijaksana dalam } \\
\text { menggunakan SDA }\end{array}$ & 3,29 & Mulai Berkembang \\
4 & $\begin{array}{l}\text { Tanggung jawab terhadap } \\
\text { lingkungan }\end{array}$ & 3,09 & Mulai Berkembang \\
\hline Rata-Rata Total & $\mathbf{3 , 2 2}$ & Mulai Berkembang \\
\hline
\end{tabular}

Berdasarkan data hasil observasi nilai keterampilan proses sains pada Tabel 9. diperoleh rata-rata nilai keterampilan proses sains siswa pada setiap indikator sebesar 85,86 dengan kategori baik. Hal ini berarti bahwa modul praktikum yang dikembangkan efektif untuk meningkatkan keterampilan proses sains siswa. Selanjutnya, data hasil observasi nilai karakter peduli lingkungan pada Tabel 10. diperoleh rata-rata skor karakter peduli lingkungan siswa pada setiap indikator sebesar 3,22 dengan kategori mulai berkembang. Hal ini berarti bahwa modul praktikum yang dikembangkan efektif untuk meningkatkan karakter peduli lingkungan siswa.

Validasi Modul praktikum ditempuh melalui tahap validasi ahli. Rata-rata skor validitas modul praktikum yang dikembangkan dilihat dari aspek kelayakan isi yaitu 3,54 dengan kriteria sangat valid, aspek kelayakan penyajian yaitu 3,37 dengan kriteria valid, dan aspek penilaian bahasa yaitu 3,30 dengan kriteria valid. Secara keseluruhan validitas modul praktikum yang berhasil dikembangkan dikategorikan valid dan layak untuk digunakan. Walaupun bahan ajar yang dikembangkan valid dan layak digunakan dalam pembelajaran, namun masih terdapat beberapa saran yang harus ditindak lanjuti untuk dilakukan revisi sehingga modul praktikum yang dikembangkan menjadi lebih baik.

Hasil penelitian validitas modul praktikum berada pada kategori valid dan layak digunakan, hal ini sejalan dengan hasil penelitian yang dilakukan oleh Meyhandoko (2013) yang mengembangkan petunjuk praktikum Kontekstual memperoleh hasil bahwa jumlah skor validasi pakar $97,2 \%$ menunjukkan bahwa petunjuk praktikum yang dikembangkan berkatagori valid dan sangat layak digunakan. Diperolehnya modul praktikum yang valid disebabkan oleh komponen modul praktikum yang dikembangkan telah sesuai dengan indikator/deskriptor yang telah ditetapkan pada instrumen validitas modul sehingga setelah dilakukan pengolahan data diperoleh skor validitas modul dalam kategori valid.

Dari hasil penelitian keterlaksanaan modul praktikum yang dikembangkan diperoleh kesimpulan bahwa modul praktikum yang dikembangkan praktis, respon guru terhadap modul yang dikembangkan adalah sangat praktis, dan respon siswa terhadap modul adalah sangat praktis.

Kepraktisan modul praktikum yang dikembangkan disebabkan oleh guru dan siswa mudah memanfaatkan bahan ajar yang dikembangkan dan dapat memanfaatkan sesuai dengan alokasi waktu yang telah ditentukan. Begitu juga, alat, bahan praktikum yang digunakan dalam kegiatan praktikum sederhana dan mudah didapat, sehingga siswa dan guru memberikan respon yang positif terhadap kegiatan praktikum yang telah dilakukan. Kegiatan praktikum dengan menggunakan pendekatan kontekstual memberikan kesempatan kepada siswa untuk berinteraksi dengan lingkungan. Dengan demikian akan mampu meningkatkan keterampilan sains siswa terhadap masalah-masalah IPA yang sedang terjadi dan peduli terhadap lingkungan. Hal ini sejalan dengan penelitian yang dilakukan oleh Robin dalam Ting \& Siew (2014) yang menyelidiki pengaruh dari pembelajaran di luar ruangan kelas (kontekstual) terhadap keterampilan proses sains dan keingintahuan ilmiah siswa menunjukkan bahwa dengan belajar di luar kelas (kontekstual) siswa mengalami peningkatan keterampilan prosese. Hal ini dikarenakan belajar di luar kelas dapat membantu siswa untuk membangun lebih banyak struktur kognitif yang kompleks dengan kegiatan nyata. Melalui interaksi antara lingkungan, siswa akan dapat menerapkan keterampilan proses sains untuk memecahkan masalah seharihari yang lebih baik. Ditinjau dari keterlaksanaan modul praktikum pada pertemuan pertama diperoleh rata-rata skor keterlaksanaan sebesar 3,18. Ini berarti bahan ajar pada pertemuan pertama praktis dilaksanakan oleh guru. Meskipun tergolong praktis, masih ada beberapa kendala yang dialami selama kegiatan praktikum pada pertemuan pertama dengan menggunakan modul praktikum yang dikembangkan. Kendala tersebut, yaitu: Pertama, manajemen waktu siswa kurang baik ketika melakukan kegiatan praktikum. Sebagian siswa menghabiskan waktu terlalu banyak untuk melakukan pengamatan sehingga mempengaruhi waktu kegiatan selanjutnya. Kedua, siswa belum terbiasa untuk melakukan praktikum sesuai petunjuk yang ada pada modul secara mandiri sehingga masih diperlukan bimbingan dari guru. Ketiga, siswa belum terbiasa untuk merumuskan hipotesis berdasarkan wacana yang diberikan, sehingga masih banyak hipotesis yang tidak sesuai dengan tujuan yang diharapkan. Keempat,

Indonesian Values and Character Education Journal|63 
dalam melakukan kegiatan praktikum yang ada pada modul praktikum, masih banyak siswa yang belum mengerti dengan prosedur praktikum yang ada pada modul. Kelima, beberapa siswa masih kurang fokus dan mengambil tanggung jawab penuh saat melakukan praktikum. Sehingga, pada saat mengkomunikasikan hasil praktikum , mereka masih mengalami kendala dan belum begitu memahami apa yang harus mereka disampaikan.

Bertolak dari kendala-kendala yang dihadapi pada pertemuan pertama, maka peneliti bersama guru IPA yang diajak mengamati keterlaksanaan pembelajaran mendiskusikan rancangan penanganan terhadap kendala-kendala yang dialami dalam pembelajaran. Rancangan penanganan yang akan diberikan berdasarkan hasil diskusi adalah sebagai berikut. Pertama, memberikan siswa instruksi yang jelas dan memastikan siswa memahami apa yang harus ia lakukan sebelum siswa melakukan kegiatan praktikum secara mandiri. Kedua, guru berusaha memotivasi siswa dengan meminta siswa mencermati kembali petunjuk kegiatan praktikum yang ada pada modul. Guru membantu siswa yang memerlukan bantuan dan perlahan-lahan bantuan dikurangi. Ini dilakukan agar siswa tidak mengalami kebingungan dan keraguan saat melakukan kegiatan yang dilakukan sehingga prosedur kerja siswa menjadi terstruktur. Ketiga, dilakukan penyesuaian pada modul praktikum dengan menertakan kata kunci untuk mengarahkan siswa dalam menyususn hipotesis. Keempat, dilakukan penyesuaian terhadap prosedur praktikum agar mudah dimengerti oleh siswa. Kelima, guru memberikan bimbingan secara intensif dengan mendampingi setiap anggota kelompok serta memotivasi siswa agar mencermati petunjuk praktikum yang ada pada modul praktikum serta melakukan kegiatan praktikum secara aktif.

Pelaksanaan kegiatan praktikum pada pertemuan kedua disesuaikan dengan refleksi terhadap kendala-kendala yang dialami pada pertemuan pertama serta upaya perbaikan yang dilakukan. Berdasarkan penanganan perbaikan-perbaikan yang dirancang peneliti dan guru IPA dapat memberikan dampak positif terhadap pelaksanaan praktikum pada pertemuan kedua. Hal ini dapat ditunjukkan dengan meningkatnya rata-rata skor keterlaksanaan modul praktikum pada pertemuan kedua. Adapun rata-rata skor keterlaksanaan pada pertemuan kedua adalah 3,33. Ini berarti bahan ajar praktis dilakukan oleh guru.

Berdasarkan refleksi pertemuan kedua ada beberapa perubahan yang menuju ke arah positif dibandingkan dengan pertemuan pertama antara lain: 1) siswa sudah mulai biasa melakukan kegiatan sesuai dengan yang dituntut pada modul praktikum. Ini ditandai dengan sikap siswa yang mulai mencermati modul dan mulai mengerjakan semua kegiatan-kegiatan yang diminta dalam modul praktikum, 2) siswa mulai terbiasa mengelola waktu yang disediakan untuk kegiatan praktikum, dan 3) Siswa mulai terbiasa menyusun hipotesis sesuai dengan tujuan praktikum yang diharapkan.

Walaupun kendala pada pertemuan pertama dapat diatasi, namun masih ada beberapa kendala yang dialami pada pertemuan kedua, yaitu: 1) ada beberapa siswa yang dalam kelompoknya masih terkesan pasif dan tidak mau aktif dalam diskusi kelompok, dan 2) siswa belum mampu mengelola waktu di rumah dengan efektif dalam mengerjakan tugas sekolah sehingga dalam mengumpulkan laporan hasil kegiatan praktikum kurang tepat waktu.

Dari kendala-kendala yang dialami pada pertemuan kedua, peneliti mendiskusikan dengan rekan-rekan guru IPA dalam upaya mencari solusi penanganan kendala-kendala tersebut antara lain: 1) memberikan motivasi kepada sisiwa dengan cara mendekati siswa yang tidak aktif dalam kelompoknya dengan menanyakan kendala-kendala yang dihadapi, dan 2) memberikan arahan kepada sisiwa supaya efisien menggunakan waktu dengan membagi tugas pada masing-masing anggota kelompoknya sehingga semua anggota kelompok memiliki rasa tanggung jawab terhadap tugas yang diberikan dan dapat mengumpulkan laporan praktikum tepat waktu.

Pelaksanaan pembelajaran pada pertemuan ketiga sesuai dengan refleksi dari kegiatan yang dilakukan pada pertemuan kedua serta upaya-upaya yang dilakukan untuk mengatasi kendala-kendala yang dihadapi. Secara umum pelaksanaan pertemuan ketiga berdampak positif setelah dilakukan perbaikan-perbaikan dengan rata-rata skor 3,72 yang dikategorikan sangat praktis.

Pada pertemuan keempat pembelajaran sudah mulai berlangsung dengan baik walaupun rata-rata skor keterlaksanaan pada pertemuan ini sedikit menurun yaitu 3,56 dengan kategori sangat praktis. Namun, pada pertemuan ini siswa sudah mulai memperlihatkan perubahan yang positif yaitu siswa terbiasa melakukan kegiatan praktikum sesuai dengan yang dituntut pada modul praktikum, siswa sudah terbiasa aktif untuk melakukan diskusi dengan teman-temannya dalam kelompok, dan gurupun sudah terbiasa melakukan pembelajaran sesuai yang diminta pada modul praktikum. 
Pada pertemuan kelima dilakukan dengan menyempurnakan dan melakukan perbaikanperbaikan pada pertemuan keempat. Pada pertemuan kelima kegiatan praktikum berlangsung dengan sangat menyenangkan, siswa sudah terbiasa melakukan praktikum secara mandiri, bahkan siswa sudah terbiasa memanfaatkan media internet untuk mencari pengetahuanpengetahuan yang berkaitan dengan kompetensi dasar yang dipelajari. Hal ini terlihat dari hasil rata-rata skor keterlaksanaan modul praktikum pada pertemuan kelima sebesar 3,77 yang mengalami peningkatan secara kuantitatif dari pertemuan sebelumnya. Begitu pula pada pertemuan keenam, dengan skor yang konsisten sebesar 3,77 berada pada katagori sangat praktis.

Kepraktisan modul praktikum juga dilihat dari respon guru dan respon siswa. Respon guru terhadap modul praktikum rata-rata skor sebesar 3,54. Berdasarkan kriteria kepraktisan yang diuraikan pada bab III, dapat dikatakan bahwa modul praktikum sangat praktis digunakan oleh guru dalam kegiatan pembelajaran. Sedangkan rata-rata skor respon siswa terhadap modul praktikum sebesar 3,53 , yang berarti modul praktikum sangat praktis digunakan oleh siswa.

Selanjutnya, efektivitas modul praktikum yang dikembangkan dapat dilihat dari skor hasil observasi keterampilan proses dan karakter peduli lingkungan siswa. Observasi keterampilan proses diberikan pada setiap kegiatan praktikum selama enam kali pertemuan. Hasil analisis keterampilan proses diperoleh nilai 85,86 menunjukan bahwa keterampilan proses sains siswa berada pada kategori baik. Jadi dapat disimpulkan kegiatan praktikum menggunakan modul praktikum kontekstual efektif untuk meningkatkan keterampilan proses sains siswa. Hasil penelitian ini sejalan dengan penelitian yang dilakukan oleh Robin dalam Ting \& Siew (2014) menunjukkan bahwa pembelajaran dengan kontekstual dapat meningkatkan keterampilan proses sains. Hal ini dikarenakan belajar secara kontekstual dapat membantu siswa untuk membangun lebih banyak struktur kognitif yang kompleks dengan kegiatan nyata. Melalui interaksi antara lingkungan, siswa akan dapat menerapkan keterampilan proses sains untuk memecahkan masalah sehari-hari yang lebih baik.Wahid (2001) juga menyatakan bahwa dengan melaksanakan praktikum secara kontekstual, praktikum akan menjadi lebih menarik dan menyenangkan bagi siswa karena dapat membawa persoalan IPA ke dalam kehidupan sehari-hari. Sejalan dengan Wahid, Crawford (2013) mengungkapkan bahwa latihan atau tugas yang realistis, otentik, menantang, dan ada relevansinya dengan dunia nyata (kontekstual) lebih efektif bagi siswa dan dapat membangun pengetahuan baru atau memperkuat pengetahuan yang sudah ada. Oleh karena itu, pendekatan CTL ini sangat relevan jika diangkat dan dipergunakan dalam kegiatan praktikum IPA karena mempertimbangkan lima hal yang merupakan bagian dari pendekatan CTL yakni; inkuiri, kerja kooperatif, aspek kontekstual, faham kontruktivisme, dan akurasi data.

Selanjutnya rata-rata nilai karakter peduli lingkungan siswa dalam penelitian ini mengalami peningkatan dari mulai terlihat sampai membudaya dengan skor rata-rata sebesar 3,22. Peningkatan nilai karakter peduli lingkungan dikarenakan dalam proses pembelajaran guru terus menerus mengingatkan dan melatih karakter siswa dengan memasukkan nilai-nilai karakter peduli lingkungan dalam modul praktikum, dengan menggunakan pembelajaran berseting kontekstual. Hal ini sejalan dengan hasil penelitian yang dilakukan Yustina \& Febrita (2013), yang menyatakan bahwa pembelajaran berbasis lingkungan (kontekstual) berdampak positif terhadap sikap dan partisipasi siswa, dengan melibatkan siswa dalam pembelajaran dengan lingkungan dapat meningkatkan budaya kepedulian siswa terhadap lingkungan.

Mulyasa (2014) menyatakan, proses penerapan karakter dalam kehidupan sehari-hari peserta didik dapat dilakukan melalui pembelajaran Kontekstual, karena pembelajaran dilakukan secara alamiah, sehingga peserta didik dapat mempraktikkan karakter-karakter yang dipelajarinya dan yang telah dimilikinya secara langsung. Pembelajaran kontekstual mendorong peserta didik memahami hakikat, makna, dan manfaat belajar, sehingga memungkinkan mereka termotivasi belajar bahkan mampu membentuk kesadaran diri untuk mempertimbangkan dan mengambil tindakan moral dalam bentuk karakter yang positif, salah satunya karakter peduli terhadap lingkungan.

\section{Simpulan dan Saran}

Berdasarkan hasil penelitian, maka dapat diajukan beberapa saran untuk mengembangkan modul praktikum dalam meningkatkan keterampilan proses sains dan karakter peduli lingkungan, yaitu; 1)Hendaknya dalam proses praktikum , siswa dikaitkan dengan dengan dunia nyata sehingga praktikum menjadi lebih bermakna dan siswa dapat 
membangun pengetahuannya sendiri, 2) Praktikum IPA hendaknya dilaksanakan sesuai dengan tuntutan Kurikulum 2013 sehingga pemahaman siswa menjadi lebih holistik tentang IPA, 3)dalam penelitian ini telah dihasilkan modul praktikum IPA Kontekstual pada materi pencemaran lingkungan. Agar diperoleh modul praktikum yang benar-banar baik perlu penyempurnaan modul yang telah dikembangkan ini, yaitu dapat diujikan pada kelas dan sekolah lain oleh guru yang berbeda namun mempunyai karakteristik yang sama, dan 4) pengembangan modul praktikum seperti ini hendaknya juga dikembangkan pada pokok bahasan dan kompetensi yang lain pada mata pelajaran IPA khususnya atau mata pelajaran lain pada umumnya.

\section{Daftar Pustaka}

Crawford, M.2013. Contextual Teaching and Learning : Strategies for Creating Constructivist Classrooms (Conclusion). 11(9): 1-6. Journal. Tersedia pada http: //www.cord.org/uploa dedfiles/Vol11No9.pdf. Diakses pada tanggal 05 Oktober 2016.

Efendi, R. 2010. Kemampuan fisika siswa Indonesia dalam TIMSS (Trend of international on mathematics and science). Prosiding Seminar Fisika 2010.

Gonzales, P., Leslie, J., Stephen, R., David, K., \& Summer, B. 2009. Highlight from TIMSS 2007: Mathematics and science achievement of u.s. fourthand eighth-grade students in an international context. Institute of Education Science.

Meyhandoko, A. 2013. Pengembangan Petunjuk Praktikum Kontekstual Dengan Pemanfaatan Kondisi Lingkungan Lokal Dalam Pembelajaran Materi Pencemaran di SMA N 2 Rembang. Sripsi. Universitas Negeri Semarang.

Mulyasa, H.E. 2013. Kurikulum yang Disempurnakan. Bandung: Remaja Rosda Karya.

Mulyasa, H.E. 2014. Manajemen Pendidikan Karakter. Jakarta: Bumi Aksara.

Nurkancana, W. \& Sunartana, P. 1986. Evaluasi Hasil Belajar. Surabaya: Usaha Nasional.

Rahmawati. 2015. Hasil TIMSS 2015 “ Diagnosa Hasil untuk Perbaikan Mutu dan Peningkatan Capaian”. Hasil Seminar. Tersedia pada http://puspendik .Kemdikbud.go.id/seminar/upload/Rahmawati-Seminar\%20Hasil\%20 TIMSS \%202015.pdf. Diakses pada tanggal 19 Desember 2016.

PISA. 2006. The PISA 2006 Assesment of Reading, Mathematical and Scientific Literacy. Tersedia pada http: //www.pisa.oecd.org. Diakses pada tanggal 17 Nopember 2016.

Satriani, I.\& Emilia, E. 2012. Contextual Teaching and Learning Approach to Teaching Writing. Indonesian Journal of Applied Linguistics. 2(1) : 10-22. Tersedia pada http:// download.portalgaruda. Org/ article.php?article $=69099 \& v a l=4819$. Diakses pada tanggal 10 Oktober 2016.

Suastra, I W., Mardana, I B P., \& Suwindra, I N P. 2006. Pengembangan Sistem Asesmen Otentik dalam Pembelajaran Fisika di Sekolah Menengah Atas (SMA). Laporan Research Grant (tidak diterbitkan). Universitas Pendidikan Ganesha Singaraja.

Suastra, I.W. 2013. Pembelajaran Sains Terkini 'Mendekatkan Siswa dengan Lingkungan Alamiah dan Sosial Budayanya'. Singaraja: Undiksha.

Ting, K.L.,\& Siew, M.,NY. 2014. Effect of Outdoor School Ground Lessons on Students" Science Process Skills and Sccientific Curiosity. Journal of Education and Learning . 3(4): 97-107. Tersedia pada http://www.ccsenet.org/journal /index.php/jel/article/viewFile/39149/23152. Diakses pada tanggal 16 Oktober 2016.

Thiagarajan, S.,Semmel, D.S., dan Semmel, M.I. 1974. Instructional Development for Training Teachers of Exceptional Children: A Sourcebook. Indiana: Indiana University. 
IVCEJ, Vol 1 No 2, Tahun 2018

p-ISSN: 2615-4684 e-ISSN: 2615-6938

Wahid, A. 2001. Kondisi Pembelajaran Ilmu Kimia dan Prospeknya pada Era Industrialisasi. Jurnal IImu Kimia dan Pembelajaran.

Wibowo, A. \& Gunawan. 2015. Pendidikan Karakter Berbasis Kearifan Lokal di Sekolah (Konsep, Strategi, dan Implementasi). Yogyakarta: Pustaka Pelajar.

Yustina \& Febrita, E. (2013). Increase Motivation and Knowledge the Environment through Contextual Model. Asian Social Science . 9(12).: 237-243. Tersedia pada http://www.ccsenet.org/journal/index.php/ass/article /view/30073. Diakses pada tanggal 16 Oktober 2016. 